\title{
Epidemiological surveillance of capybaras and ticks on warning area for Brazilian spotted fever
}

\author{
José Brites-Neto ${ }^{1}$, Jardel Brasil ${ }^{1}$ and Keila Maria Roncato Duarte ${ }^{2}$
}

1. Department of Epidemiological Surveillance, Secretariat of Health, Americana, São Paulo, Brazil; 2. Department of Genetics and Animal Reproduction, Institute of Animal Science, Nova Odessa, São Paulo, Brazil.

Corresponding author: José Brites-Neto, e-mail: samevet@yahoo.com.br,

JB: jarbrasa@hotmail.com, KMRD: keiladuarte@globo.com

Received: 05-03-2015, Revised: 19-08-2015, Accepted: 28-08-2015, Published online: 30-09-2015

doi: 10.14202/vetworld.2015.1143-1149 How to cite this article: Brites-Neto J, Brasil J, Duarte KMR (2015) Epidemiological surveillance of capybaras and ticks on warning area for Brazilian spotted fever, Veterinary World 8(9):1143-1149.

\begin{abstract}
Aim: The vulnerability of tropical developing countries to the emerging disease constitutes a critical phenomenon in which the invasion of wild niches by human hosts, contributes to expansion of zoonotic diseases, such as the Brazilian spotted fever (BSF). This study performed a diagnosis of species occurrence of their hosts (Hydrochoerus hydrochaeris) and vectors (Amblyomma sculptum and Amblyomma dubitatum) on the warning area for this reemerging disease in Brazil.

Materials and Methods: The study was conducted in a warning area for BSF in the city of Americana, São Paulo state. The occurrence of capybaras was registered by use of binoculars and GPS equipment and 24 acarological researches were performed through $180 \mathrm{CO} 2$ traps. Samples of adult ticks were dissected for salivary glands removal, DNA extraction, and evaluation by polymerase chain reaction (PCR) being tested by initial gltA-PCR, ompA-PCR, and Rickettsia bellii-specific PCR, with the positive samples subjected to sequencing.

Results: Eleven clusters of capybaras (total of 71 individuals), were observed along the riparian of Ribeirão Quilombo and 7,114 specimens of $A$. sculptum and 7,198 specimens of $A$. dubitatum were collected in this same area. About 568 samples of adult ticks were dissected for salivary glands removal, DNA extraction and evaluation by gltA-PCR, with results of $1.94 \%$ (11/568) of positive samples. Results for the initial gltA-PCR indicated none positive sample to Rickettsia species into A. sculptum and 11 positive samples to A. dubitatum. These samples were negative to the ompA-PCR and positive to the Rickettsia bellii-specific PCR protocol and subjected to DNA sequencing, whose result indicated $100 \%$ similarity to Rickettsia bellii. The distribution of tick species A. sculptum and A. dubitatum was configured regarding to the biotic potential of the riparian areas, measuring the risks for BSF in peri-urban areas of Americana.
\end{abstract}

Conclusion: These results confirmed a status of epidemiological warning with a strong association of the amplifiers hosts of Rickettsia and tick vectors for the transmission of BSF to humans in this region.

Keywords: acarological research, Amblyomma dubitatum, Amblyomma sculptum, Hydrochoerus hydrochaeris, riparian forests, Rickettsia spp.

\section{Introduction}

The Brazilian spotted fever (BSF) is a disease from compulsory notification, with incidence and prevalence associated to risk of human parasitism by tick vectors, which makes acarological surveillance, be extremely important for efficient control of this disease [1]. Their etiologic agent (Rickettsia rickettsii) presents large pathogenicity and genetic variability, with more virulent circulating genotypes, establishing wide variation in lethality rates [2] and although determine low morbimortality in the population is among the most lethal etiologic agent of all known infectious diseases [3].

Their transmission occurs exclusively by ticks and in the São Paulo state, Amblyomma sculptum in the central part and Amblyomma aureolatum in the eastern part, has been implicated in the transmission of $R$. rickettsii to humans [4].

Copyright: The authors. This article is an open access article licensed under the terms of the Creative Commons Attributin License (http:// creativecommons.org/licenses/by/2.0) which permits unrestricted use, distribution and reproduction in any medium, provided the work is properly cited.
In the period 2003-2008, there was a significant expansion of the transmission areas, with the occurrence of 240 cases and 71 deaths in urban and peri-urban areas, with a lethality rate of $21.9-40 \%$ in the state of São Paulo, demonstrating deep modification in the eco-epidemiological characteristics of this disease [5].

Microbiological infections acquired from animals, known as zoonoses, have an enormous risk to public health, where $60 \%$ of emerging human pathogens are zoonotic, and more than $71 \%$ of these have their origin in wildlife. These pathogens can switch hosts for the acquisition of new genetic combinations that alter its pathogenic potential or by changes in behavior or socioeconomic, environmental, or ecological characteristics of hosts. Changes from natural habitats generate ecological imbalances that determine significant modifications in the diversity of interactions between reservoirs, hosts and vectors, increasing the chance of transmission of this disease [6], where the potential distribution of capybara is associated with anthropogenic environments, particularly by the intensive agricultural use [7]. 
At the same time, the effects of climate change in the ecology of landscapes resulted in an expansion of the number of ticks and biological hosts, with the consequent expansion of areas of risk to human or animal health in recent years [8].

The emergence and reemergence of diseases transmitted by ticks reached an overall increase of high significance as biological phenomena characterized by changes on environmental and human behavior [9] in consequence to the territorial mixture of wildlife, domestic animals and humans, combined with habitat fragmentation and increasing of circulation pathogenic microorganisms from natural areas to humans [10].

In the case of BSF, another aggravating factor in its epidemiology is the biological characteristic of A. sculptum as true reservoir of rickettsiae in nature, where all evolutionary stages are able to remain infected, ensuring a focus of prolonged disease transmission. In general, the tick A. sculptum is the most prevalent species in domestic and wild animals and in the environment, being the main vector specie to establish a bridge to pathogenic bioagents between domestic and wild fauna. The human parasitism by A. sculptum is common, because of their aggressiveness toward humans, being the principal vector of Rickettsia rickettsii, the etiologic agent of lethal spotted fever in Brazil [11].

The capybara (Hydrochoerus hydrochaeris) can be used as a sentinel for rickettsial diseases, as the $\mathrm{BSF}$, seen evidencing the circulation of rickettsiae suggesting their involvement in the life cycle of this bacterium [12-14]. An overpopulation of capybaras in certain endemic areas of BSF will be accompanied by a high environmental infestation for all parasitic stages of A. sculptum and A. dubitatum [9,15]. Therefore, capybaras in urban areas should be considered synanthropic species and effective methods of population control need to be developed [16]. Is there any relationship between the increase in capybara populations and the reemergence of the disease in many areas at São Paulo State, since the capybaras population and the number of cases of BSF increased significantly during the past three decades [17].

Capybaras are social mammals (large rodents) widely distributed in riparian habitats and much favored by the landscape alteration in a watershed anthropogenically modified, with their strong relationship with water as a resource for many activities turned streams and rivers into corridors of intermittent flow, where competition for water and food, under a social and gregarious intrinsic territoriality may provide a strong relationship with the dispersion mechanisms [18]. Seasonal fluctuations in the amount of food available exert impacts on ecological aspects of the behavior of the capybara, conditioning the group size and the increased frequency of young individuals [19].

The impacts generated by the expansion of sugarcane in São Paulo on biodiversity of wildlife, on environment and on public health have shown an increase in the abundance of rodents and eutrophication of their aquatic ambience resulting in the appearance of infectious diseases associated with wildlife, as the hantavirus, leptospirosis, and spotted fever in humans. Sugarcane plantations have a lower diversity of wild species, but significantly greater abundance of rodents that other local ecosystems, because crops of sugar cane can provide a considerable amount of food for capybaras (H. hydrochaeris) who have experienced a large increase in its population, associated with the expansion of sugar cane in the center-east of the state of São Paulo and whose growth has been associated with the local resurgence of spotted fever [20].

Epidemiological observations indicate that the capybara (H. hydrochaeris) is not a potential reservoir for BSF, no presenting the clinical signs of disease, but acting as an excellent amplifier host, disseminating the bacteria $R$. rickettsii in nature and infecting about $30 \%$ of the ticks during period of the rickettsemia [12,21]. These correlations admit the possibility of that imbalances promoted by the intervention of environmental agencies in the protection and preservation of capybaras groups, generate rapid recovery of this species that, without natural predators and into natural habitat degraded, becomes a synanthropic population in urban areas, increasing risks to BSF cases in the public parks and municipal dams.

Capybaras are very abundant in endemic areas for BSF, acting as primary hosts for all parasitic stages of A. sculptum and A. dubitatum, and as a competent amplifier host for $R$. rickettsii. This study in Americana City, São Paulo State, performed a diagnosis of species occurrence of their hosts (H. hydrochaeris) and vectors (A. sculptum and A. dubitatum) on the warning area for this reemerging disease in Brazil.

\section{Materials and Methods}

\section{Ethical approval}

This study was subject to the regulations of Publics Policies and Ethics Committee in Brazil by authorization $\mathrm{n}^{\circ} 20562$ for activities with scientific purpose, issued by the System of Authorization and Information on Biodiversity (SISBIO) of Chico Mendes Institute for Biodiversity Conservation (ICMBio).

\section{Study area}

According to epidemiological criteria, the study was conducted in a warning area for BSF in the city

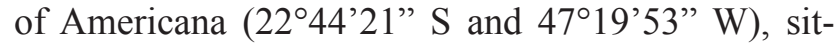
uated in a hydrographic basin composed for a dam and four rivers, in the state of São Paulo. This area located in an urban region of the municipality with a population 2,500 residents is characterized by riparian forests along 7,650 meters of the Ribeirão Quilombo. Americana is a municipality located in the eastern part of the state of São Paulo, southeastern Brazil, with a population of 224,551 inhabitants [22]. The existence of a rich hydrography created a highly favorable environment for the density of capybaras in their territory (Figure-1). 


\section{Observation of capybara groups}

The staff at surveillance and control ticks from the Department of Health from Americana, passing through the whole course of Ribeirão Quilombo conducted a situational diagnosis of capybara groups distributed along the riparian areas and began an observation of population groups by use of optical instruments (Romitar binoculars with zoom ranging from 15 to 180 times, $100 \mathrm{~mm}$ lens and view field of $52 \mathrm{~m} / 1000 \mathrm{~m}$ ) and GPS equipment (Garmin eTrex Summit HC).

The occurrence of capybaras in these locations was verified through detection of footprints and traces of faeces to localization and observation of individuals.

\section{Acarological research}

About 24 acarological researches were distributed into $180 \mathrm{CO}_{2}$ traps, at different points of riparian forest of Ribeirão Quilombo (Figure-2). The free-living ticks were collected after $1 \mathrm{~h}$ in the traps containing $800 \mathrm{~g}$ of dry ice in weekly repeated procedure between 09:00 am and 12:00 am [23] and were examined under a stereoscopic microscope for adults identification, sexed and classified taxonomically according to dichotomous keys translated and modified [24].

The collected larvae were identified by morphological criteria, and differentiated as the largest body size, oval outline in A. dubitatum, in comparison to A. sculptum [25] and nymphs characterized by taxonomic identification key of Amblyomma species [26].

\section{Molecular analysis}

All adult specimens of ticks collected were placed in $1.5 \mathrm{~mL}$ microtubes and stored at $-80^{\circ} \mathrm{C}$, for DNA extraction and polymerase chain reaction (PCR) analysis. To evaluate the potential infectivity for

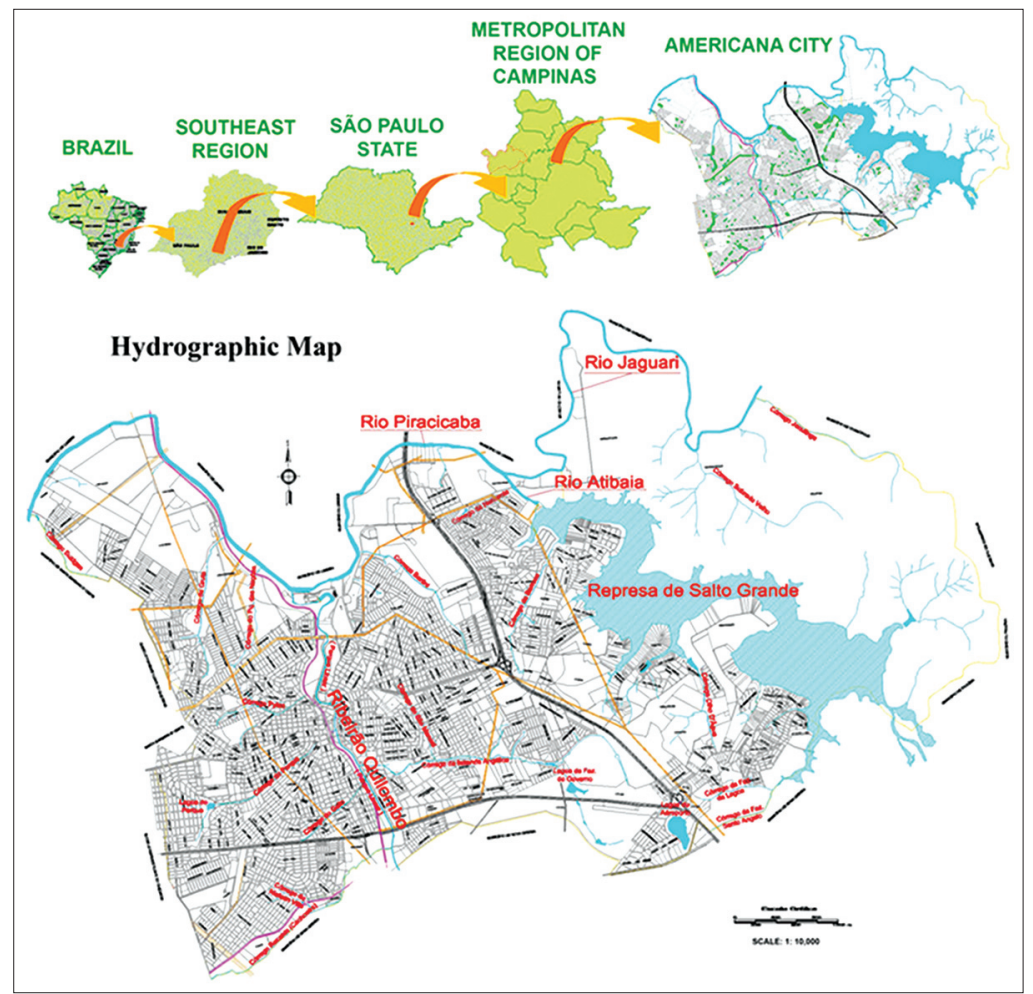

Figure-1: Map of Americana presenting their rich hydrography highly favorable for the density of capybaras into their territory.

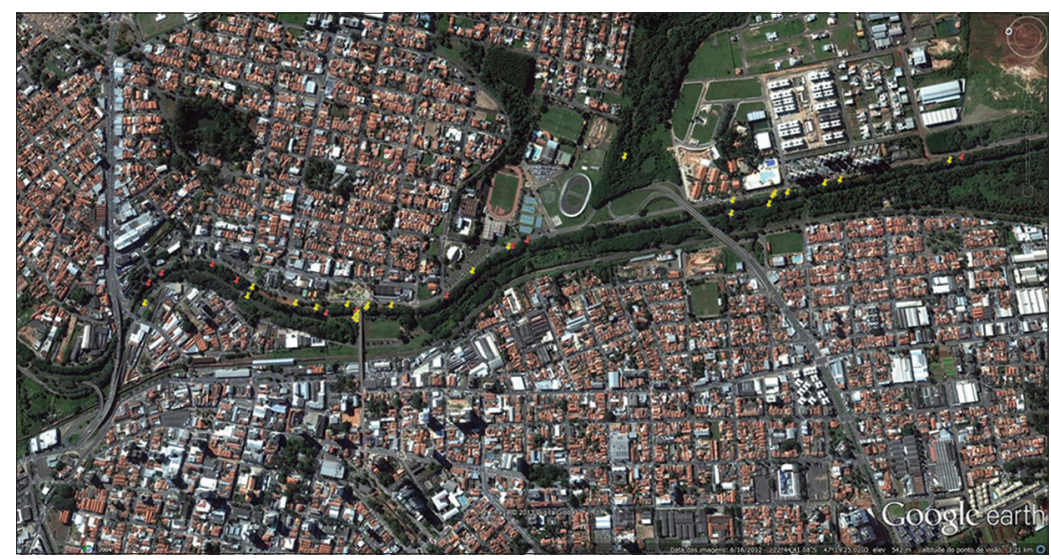

Figure-2: Spatial distribution of the clusters of capybaras (red mark) and acarological researches (yellow mark), georeferenced at different points in the riparian forest of Ribeirão Quilombo. Americana, São Paulo, Brazil. 
Rickettsia, each adult ticks was thawed and subjected to identification, separation and dissection to removal of salivary glands under a stereomicroscope [27] for DNA extraction, through the GT protocol (chloroform and guanidine isothiocyanate) [28] and tested by Rickettsia genus-specific PCR using primers CS-62/CS-462, targeting a 401-bp fragment for citrate synthase gene of Rickettsia spp. (gltA) [29].

The PCR has been used for detection of Rickettsia spp. in gross crushed ticks, by amplification of glt $A$ gene fragment, being positive samples for this gene subjected to amplification of $r O m p A$ gene for identification of spotted fever group rickettsiae (SFG). The PCR followed by sequencing gene permits identification and phylogenetic analysis of different species of rickettsiae. Through PCR can be assessed several specific genes of rickettsiae such as 16S rRNA, the gltA (citrate synthase), found in all species of rickettsiae [29] and genes that encode proteins $O m p A$ and $O m p B$, important in the pathogenesis of SFG rickettsiae.

The gltA-positive samples were tested by two others PCR, one assay using primers Rr190.70 $\mathrm{p} / \operatorname{Rr} 190.602 \mathrm{n}$, which amplified a 532-pb fragment

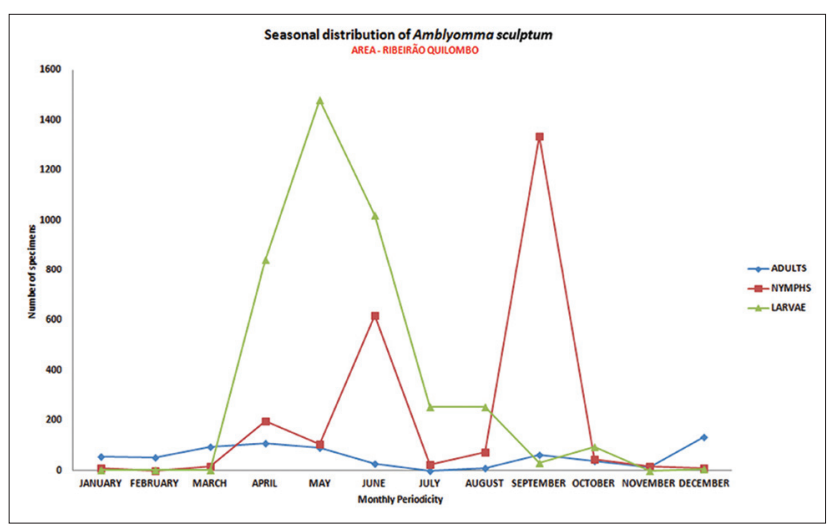

Figure-3: Seasonal distribution of the population of adults, nymphs and larvae of Amblyomma sculptum. Riparian forest. July 2009 to June 2010. Warning area for Brazilian spotted fever. Ribeirão Quilombo, Americana, São Paulo, Brazil [25].

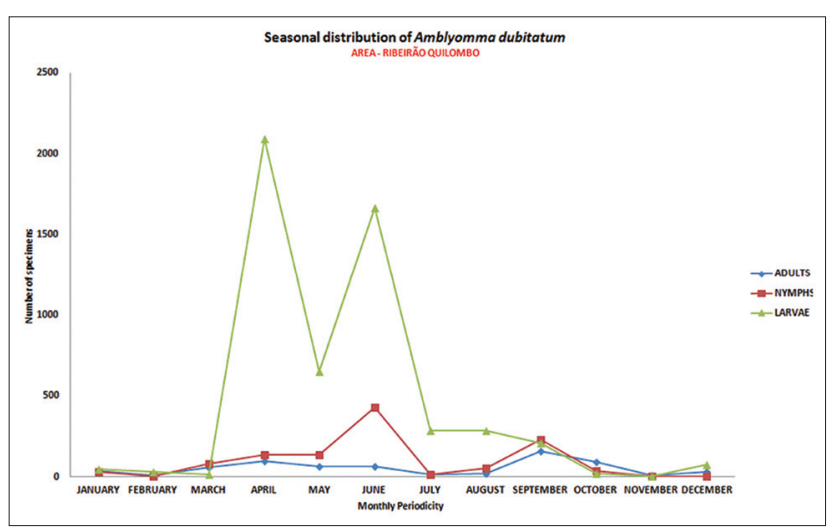

Figure-4: Seasonal distribution of the population of adults, nymphs and larvae of Amblyomma dubitatum. Riparian forest. July 2009 to June 2010. Warning area for Brazilian Spotted Fever. Ribeirão Quilombo, Americana, São Paulo, Brazil [25]. for the outer membrane protein gene of Rickettsia (ompA) which is specific for the SFG [30], and another assay specific to Rickettsia bellii, using the primers 5'-ATCCTGATTTGCTGAATTTTTT-3' (forward) and 5'-TGCAATACCAGTACTGACG-3' (reverse), which amplified a 338-bp fragment of the $R$. bellii gltA gene [31]. The amplified material was purified by ExoSAP-IT ${ }^{\circledR}$ (USB ${ }^{\circledR}$ Corporation) and subjected to sequencing using "BigDye Kit 3.1" and the DNA sequencer ABI Model "PRISM 3100 Genetic Analyzer" (Applied Biosystems, Foster City, CA, USA). The sequences obtained were submitted to the "BLAST analysis" software (National Center for Biotechnology Information, Bethesda, MD, USA) to determine the similarities of the partial rickettsial sequences generated in the current study [32].

\section{Results}

14,312 ticks (7,114 specimens of $A$. sculptum and 7,198 specimens of $A$. dubitatum) were collected and a total of 681 adult specimens of $A$. sculptum (301 males and 380 females) and 658 adult specimens of $A$. dubitatum ( 320 males and 338 females) were identified. 2,447 nymphs and 3,986 larvae of A. sculptum and 1,160 nymphs and 5,380 larvae of $A$. dubitatum were identified.

The distribution of seasonal patterns of A. sculptum (Figure-3) and A. dubitatum (Figure-4) were characterized by the presence of adults and immatures during all months of the period, in the areas of riparian forest of Ribeirão Quilombo analyzed at the municipality of Americana.

The human infestation was actively observed by adults, nymphs and larvae of A. sculptum and A. dubitatum in all acarological research conducted in the warning area studied, through the human parasitism record in workers staff involved in this activity.

At epidemiological point of view, depending on the relation between vectors, their hosts and the occurrence of human infestation in the area of riparian forest surveyed, it was observed a higher prevalence of A. dubitatum (58.4\%) against A. sculptum (41.6\%), associated to respective presence of capybaras, opossums, horses and dogs observed in this area.

568 samples of adult ticks were dissected for salivary glands removal, DNA extraction and evaluation by gltA-PCR, with results of $1.94 \%(11 / 568)$ of positive samples. Analyzing the results by species, no positive results for A. sculptum and 3.63\% (11/303) of samples to $A$. dubitatum were positive.

The 11 samples positive for the initial gltA-PCR were negative to the ompA-PCR and positive to the Rickettsia bellii-specific PCR protocol. PCR products were subjected to DNA sequencing, where all the sequences obtained showed $100 \%$ similarity to the corresponding sequence of $R$. bellii in GenBank (accession number CP000087).

Eleven clusters of capybaras (represented by two different couples, two satellite females, and seven familiar social groups) were observed and identified at $7.65 \mathrm{~km}$ of riparian vegetation along Ribeirão 
Quilombo (Figure-2). Each social group ranged from 03 to 19 individuals. Three adult males, 20 adult females, 20 juvenile females, and 28 cubs in a total of 71 individuals were observed, and were mapped 57 shelters, refuges, or rest areas; 12 transit areas defined by tracks with footprints and 08 grazing areas.

\section{Discussion}

The seasonal activity of free-living stages seeking a host, and the population density of ticks that perform human parasitism, can directly affect the occurrence of BSF in a region, for there are also seasonal prevalence for disease, as well as the stages of the tick, where most cases occur in the months from September to November (spring and early summer), more frequent at the time of predominance of larvae and nymphs compared to adults ticks that have lower predilection for parasitism in humans.

Regarding the main vector of BSF, recent studies reassessed the taxonomic status of Amblyomma cajennense through morphological and molecular analyzes, indicating a complex of six species (A. cajennense sensu stricto Fabricius, 1787, Amblyomma tonelliae Nava, Beati and Labruna, 2014, Amblyomma interandinum Beati, Nava and Cáceres, 2014, Amblyomma patinoi Labruna, Nava and Beatos, 2014, Amblyomma mixtum Koch, 1844 and A. sculptum Berlese, 1888 [33]. As a result, two species of ticks have been validated for Brazil (A. cajennense sensu stricto and $A$. sculptum) within the complex $A$. cajennense, causing the new name of $A$. sculptum for the species in the state of São Paulo. Therefore, the A. sculptum species presents the capybara ( $H$. hydrochaeris Linnaeus, 1776) as a primary host for all your parasitic stages (adults, nymphs, and larvae) [14].

A. sculptum presents an annual pattern generation in the Southeast region of Brazil, with the three stages markedly distributed throughout the year. The larvae occur primarily between the months from March to July. The nymphs between the months from July to November, and adults predominantly between the months from November to March controlled by behavioral diapause during one phase of the life cycle [34], also having great interference of photoperiod and climatic variables on the level of environmental infestations studied.

Based on analysis of the scientific literature, the human parasitism by $A$. sculptum was reported in 23 municipalities and by $A$. dubitatum in three municipalities of the state of São Paulo [35]; and during the last 10 years in the state of São Paulo, the number of confirmed cases of BSF by location was similar among endemic areas, where A. aureolatum or A. sculptum were the vectors [36].

Considering the seasonal distribution analysis, the prevalence of species of $A$. sculptum and $A$. dubitatum, and the epidemiological profile established with the incidence of ten cases of BSF and six deaths in humans in the respective study areas, from 2004 to
2013, was proven the epidemiological risk of active transmission of this zoonosis in the municipality of Americana, São Paulo state [25]. All these cases were related to tick bites acquired along the water courses of the municipality, where there are established populations of capybaras, with an association very alarmingly, considering that human infestation by ticks has become very common in these urban areas, with a significant population susceptible to the highlighted risks.

The increase in capybara populations during the last decades may be related to the reemergence of BSF in many areas in São Paulo State. Besides the transmission risks of this zoonosis to communities and workers in these areas, we know that its main natural host, the capybara (H. hydrochaeris) are very selective about the food, competing with cattle in pastures, creating a common and narrow convivial with these farm animals and acting as an important wild and rural reservoir of diseases and an excellent amplifier of arthropod vectors, with significant performance and important mechanisms and flows for sustainability related to disease cycles in Animal and Public Health, and its interrelationships in economic losses in livestock breeding and commercial exploitation of domestic livestock species [37].

The increasing expansion of cities have pressured the wildlife animals to live adapted in fragments of green areas threatened by the continuous reduction on natural areas [38].

The increase in capybaras populations in small riparian forest or in lakes and dams forest fragments (characterizing environmental protection areas in agricultural production units) is associated with unbearable levels of environmental infestations by ticks from the species $A$. sculptum and $A$. dubitatum. Humans and domestic animals in such places are constantly exposed to parasitism and the risk of tick-borne diseases, such as the BSF [39].

The behavioral changes observed in these individuals (gregarious animals with agonistic interactions in respect to dominance hierarchy), due to the loss of their natural sense of preservation (flight distance from) to humans caused an increase in reporting of human parasitism by ticks, due to common frequency of these animals hosts, in these urban areas.

The infection of capybaras (H. hydrochaeris) by $R$. rickettsii and its role as amplifier host for the horizontal transmission of $R$. rickettsii to $A$. sculptum tick was evaluated by extraction of DNA samples of ticks, followed by real-time PCR targeting the gltA gene from Rickettsia and detection of antibodies to $R$. rickettsii by IFA in blood serum samples of capybaras and guinea pig [12]. As a result, 20-35\% of the ticks fed in tested groups of capybaras became infected, indicating that $R$. rickettsii was capable of infecting capybaras without clinical harm to their host, but inducing a bacteremia able to cause infection in guinea pig and ticks, indicating that $H$. hydrochaeris truly acts as an amplifier host of $R$. rickettsii to A. sculptum in Brazil. 
A case study was presented where the focus of concern of management in a protected area shifted from a clear public condemnation of a wild species (capybara), for a proposed landscape management and communication in order to reduce the exposure of people to ticks, reducing risks of diseases associated with them. Forms of Rickettsia found did not belong to the SFG, but this information did not reduce the concern for health monitoring and care with exposure to ticks [40].

Unexpected changes in distribution and abundance of species has often been attributed to the complexity of nature, where many of the ecological surprises we have faced over the centuries (pandemics, population collapse of species, and major changes in ecosystems) were caused or favored by the extinction of predating species and/or the introduction of wild species for economic exploitation [41].

Despite an epidemiological characterization of warning and a prevalence of $1.94 \%$ to $R$. bellii in the studied area, the results derived from molecular analyzes, no showed rickettsiae of the SFG, in species of A. sculptum and A. dubitatum, probably due to deleterious effect caused by $R$. rickettsii in these ticks [42].

\section{Conclusion}

Thus, the work of monitoring of this population of circulating capybaras in Ribeirão Quilombo, serological surveys performed in sentinel animals and bioecological studies of ticks with information about their population dynamics, related to the host and the environment, can ensure the implementation of an effective program to arthropods control and prevention of $\mathrm{BSF}$, through monitoring by the molecular diagnostic tools in perfect sync with the instruments of epidemiological and serological surveillance, intensified by an active acarological surveillance and a syndromic surveillance for human patients suspected.

\section{Authors' Contributions}

The observation of capybara groups, acarological researches, taxonomic identification of ticks and molecular analysis were conducted by JBN and JB. Data were collected and interpreted by JBN. The manuscript was prepared jointly by JBN and KMRD. All authors read and approved the final manuscript.

\section{Acknowledgments}

The authors are grateful to the staff of the Surveillance Program and Control of Ticks from the Health Department of Americana, São Paulo State, Brazil, in special to the officer, Vectors Control, Jesus Tendor, who actively participated in the field work conducted in this research. The authors also are thankful to Prof. Marcelo Bahia Labruna, D.V.M., Ph.D. and Prof. Fernanda Aparecida Nieri-Bastos, D.V.M., $\mathrm{Ph} . \mathrm{D}$. by support conferred at the moleculer analysis in the Department of Veterinary Medicine Preventive and Animal Health, Faculty of Veterinary Medicine and Animal Science, University São Paulo-SP.

\section{Competing Interests}

The authors declare that they have no competing interests.

\section{References}

1. Pinter, A., França, A.C., Souza, C.E., Sabbo, C., Nascimento, E.M.M., Santos, F.C.P., Labruna, M.B., Holcman, M.M., Alves, M.J.C.P., Horta, M.C., Mascheretti, M., Mayo, R.C., Angerami, R.N., Brasil, R.A., Souza, S.S.A.L., Colombo, S. and Oliveira, V.L.M. (2011) Febre maculosa brasileira. Boil. Epidemiol. Paul, 8(1): 1-31.

2. Parola, P., Labruna, M.B. and Raoult, D. (2009) Tick-borne rickettsioses in America: Unanswered questions and emerging diseases. Curr. Infect. Dis. Rep., 11(1): 40-50.

3. Paddock, C.D., Denison, A.M., Lash, R.R., Liu, L., Bollweg, B.C., Dahlgren, F.S., Kanamura, C.T., Angerami, R.N., Pereira dos Santos, F.C., Martines, R.B. and Karpathy, S.E. (2014) Phylogeography of Rickettsia rickettsii genotypes associated with fatal rocky mountain spotted fever. Am. J. Trop. Med. Hyg., 91(3): 589-597.

4. Ogrzewalska, M., Saraiva, D.G., Moraes-Filho, J., Martins, T.F., Costa, F.B., Pinter, A. and Labruna, M.B. (2012) Epidemiology of Brazilian spotted fever in the Atlantic Forest, state of São Paulo, Brazil. Parasitology, 139(10): 1283-1300.

5. Katz, G., Neves, V.L.F.C., Angerami, R.N., Nascimento, E.M.M. and Colombo, S. (2009) Epidemiological situation and importance of spotted fever in São Paulo. Bol. Epidemiol. Paul., 6(69): 4-13.

6. Cutler, S.J., Fooks, A.R. and Poel, W.H.M. (2010) Public health threat of new, reemerging, and neglected zoonoses in the industrialized World. Emerg. Infect. Dis., 16(1): 1-7.

7. Ferraz, K.M.P.M., Peterson, A.T., Scachetti-Pereira, R., Vettorazzi, C.A. and Verdade, L.M. (2009) Distribution of capybaras in an agroecosystem, Southeastern Brazil, based on ecological niche modeling. J. Mammal., 90(1): 189-194.

8. Nicholson, W.L., Allen, K.E., Mcquiston, J.H., Breitschwerdt, E.B. and Little, S.E. (2010) The increasing recognition of rickettsial pathogens in dogs and people. Trends Parasitol., 26(4): 205-212.

9. Pascoal, J.O., Amorim, M.P., Martins, M.M., Melo, C., Silva Júnior, E.L., Ogrzewalska, M., Labruna, M.B. and Szabó, M.P.J. (2013) Ticks on birds in a savanna (Cerrado) reserve on the outskirts of Uberlândia, Minas Gerais, Brazil. Rev. Bras. Parasitol. Vet., 22(1): 46-52.

10. Queirogas, V.L., Del Claro, K., Nascimento, A.R. and Szabó, M.P. (2012) Capybaras and ticks in the urban areas of Uberlândia, Minas Gerais, Brazil: Ecological aspects for the epidemiology of tick-borne diseases. Exp. Appl. Acarol., 57(1): 75-82.

11. Garcia, M.V., Silva, D.C., Almeida, R.F.C., Cunha, R.C., Matias, J., Barros, J.C., Andreotti, R. and Szabó, M.P.J. (2013) Environmentally associated ticks (Acari: Ixodidae) in campo grande, mato grosso do sul, Brazil. Rev. Bras. Parasitol. Vet., 22(1): 124-128.

12. Souza, C.E., Moraes-Filho, J., Ogrzewalska, M., Uchoa, F.C., Horta, M.C., Souza, S.S.L., Borba, R.C.M. and Labruna, M.B. (2009) Experimental infection of capybaras Hydrochoerus hydrochaeris by Rickettsia rickettsii and evaluation of the transmission of the infection to ticks Amblyomma cajennense. Vet. Parasitol., 161(1-2): 116-121.

13. Fortes, F.S., Santos, L.C., Cubas, Z.S., Barros-Filho, I.R., Biondo, A.W., Silveira, I., Labruna, M.B. and Molento, M.B. (2011) Anti-Rickettsia spp. antibodies in free-ranging and captive capybaras from Southern Brazil. Pesq. Vet. Bras., 31(11): 1014-1018.

14. Krawczak, F.S., Nieri-Bastos, F.A., Nunes, F.P., Soares, J.F., Moraes-Filho, J. and Labruna, M.B. (2014) Rickettsial infection in Amblyomma cajennense ticks and capybaras (Hydrochoerus hydrochaeris) in a Brazilian spotted fever-endemic area. Parasit. Vectors, 7(7): 1-7. 
15. Nava, S., Venzal, J.M., Labruna, M.B., Mastropaolo, M., González, E.M., Mangold, A.J. and Guglielmone, A.A. (2010) Hosts, distribution and genetic divergence (16S rDNA) of Amblyomma dubitatum (Acari: Ixodidae). Exp. Appl. Acarol., 51(4): 335-351.

16. Queirogas, V.L. (2010) Capivaras (Rodentia) e carrapatos (Acari: Ixodidae): Ecological changes and the interaction of host and parasite in urban areas. Master's Thesis in Ecology and Conservation of Natural Resources. Submitted to Federal University of Uberlândia, Uberlândia, Brazil.

17. Labruna, M.B. (2013) Brazilian spotted fever: The role of capybaras. In: Moreira, J.R., Ferraz, K.M.P.M., Herrera, E.A. and MacDonald, D.W. Capybara: Biology, Use and Conservation of an Exceptional Neotropical Species. Springer Science Business Media, New York. p371-383.

18. Alho, C.J.R. and Silva, J.S.V. (2012) Effects of severe floods and droughts on wildlife of the pantanal wetland (Brazil) - A review. Animals, 2: 591-610.

19. Alho, C.J.R. and Sabino, J. (2012) Seasonal pantanal flood pulse: Implications for biodiversity conservation - A review. Oecol. Aust., 16(4): 958-978.

20. Verdade, L.M., Gheler-Costa, C., Penteado, M. and Dotta, G. (2012) The impacts of sugarcane expansion on wildlife in the state of São Paulo, Brazil. J. Sustain. Bioenergy Syst., 2: 138-144.

21. Souza, C.E., Pinter, A. and Donalisio, M.R. (2015) Risk factors associated with the transmission of Brazilian spotted fever in the Piracicaba river basin, State of São Paulo, Brazil. Rev. Soc. Bras. Med. Trop., 48(1): 11-17.

22. Feliciano, M.A.M. (2014) Informativo Sócio-Econômico do Município de Americana-SP, 30. Ano Base - 2013. Americana: SEPLAN - Unidade de estatística e análise sócioeconômica; 2014. Available from: http://www.americana. sp.gov.br/v6/download/planejamento/D032 Informativo SocioEconomico_2014.pdf. Cited on 07-09-2014.

23. Souza, S.S.A.L., Souza, C.E., Rodrigues-Neto, E.J. and Prado, A.P. (2006) Dinâmica sazonal de carrapatos (Acari: Ixodidae) na mata ciliar de uma área endêmica para febre maculosa na região de Campinas, São Paulo, Brasil. Cien. Rural, 36(3): 887-891.

24. Onofrio, V.C., Labruna, M.B., Pinter, A., Giacomin, F.G. and Barros-Battesti, D.M. (2006) Comentários e chaves para as espécies do gênero Amblyomma. In: BarrosBattesti, D.M., Arzua, M. and Bechara, G.H., editors. Ticks of Importance Veterinarian of the Neotropical Region: An Illustrated Guide to Species Identification. Vox/ICTTD-3/ Butantan, São Paulo. p53-71.

25. Brites-Neto, J., Nieri-Bastos, F.A., Brasil, J., Duarte, K.M.R., Martins, T.F., Veríssimo, C.J., Barbieri, A.R.M. and Labruna, M.B. (2013) Environmental infestation and rickettsial infection in ticks in a Brazilian spotted fever-endemic area. Rev. Bras. Parasitol. Vet., 22(3): 367-372.

26. Martins, T.F., Onofrio, V.C., Barros-Battesti, D.M. and Labruna, M.B. (2010) Nymphs of the genus Amblyomma (Acari: Ixodidae) of Brazil: Descriptions, redescriptions, and identification key. Ticks Tick Borne Dis., 1(2): 75-99.

27. Edwards, K.T., Goddard, J. and Varela-Stokes, A.S. (2009) Examination of the internal morphology of the ixodid tick, Amblyomma maculatum Koch, (Acari: Ixodidae); A "How-to" pictorial dissection guide. Midsouth. Entomol., 2(1): 28-39.

28. Sangioni, L.A., Horta, M.C., Vianna, M.C.B., Gennari, S.M., Soares, R.M., Galvão, M.A.M., Schumaker, T.T.S., Ferreira, F., Vidotto, O. and Labruna, M.B. (2005) Rickettsial infection in animals and Brazilian spotted fever endemicity. Emerg. Infect. Dis., 11(2): 265-270.

29. Labruna, M.B., Whitworth, T., Horta, M.C., Bouyer, D.H., Mcbride, J.W., Pinter, A., Popov, V., Gennari, S.M. and Walker, D.H. (2004) Rickettsia species infecting Amblyomma cooperi ticks from an area in the state of São
Paulo, Brazil, where Brazilian spotted fever is endemic. J.Clin. Microbiol., 42(1): 90-98.

30. Regnery, R.L., Spruill, C.L. and Plikaytis, B.D. (1991) Genotypic identification of rickettsiae and estimation of intraspecies sequence divergence for portions of two rickettsial genes. J. Bacteriol., 173(5): 1576-1589.

31. Szabó, M.P., Nieri-Bastos, F.A., Spolidorio, M.G., Martins, T.F., Barbieri, A.M. and Labruna, M.B. (2013) In vitro isolation from Amblyomma ovale (Acari: Ixodidae) and ecological aspects of the Atlantic rainforest Rickettsia, the causative agent of a novel spotted fever rickettsiosis in Brazil. Parasitology, 140(6): 719-728.

32. Altschul, S.F., Gish, W., Miller, W., Myers, E.W. and Lipman, D.J. (1990) Basic local alignment search tool. J. Mol. Biol., 215: 403-410.

33. Nava, S., Beati, L., Labruna, M.B., Cáceres, A.G., Mangold, A.J. and Guglielmone, A.A. (2014) Reassessment of the taxonomic status of Amblyomma cajennense (Fabricius, 1787) with the description of three new species, Amblyomma tonelliae n. sp., Amblyomma interandinum n. sp. and Amblyomma patinoi n. sp., and reinstatement of Amblyomma mixtum Koch, 1844, and Amblyomma sculptum Berlese, 1888 (Ixodida: Ixodidae). Ticks Tick Borne Dis., 5(3): 252-276.

34. Guedes, E. and Leite, R.C. (2008) Dinâmica sazonal de estádios de vida livre de Amblyomma cajennense e Amblyomma dubitatum (Acari: Ixodidae) numa área endêmica para febre maculosa, na região de coronel pacheco, minas gerais. Rev. Bras. Parasitol. Vet., 17 Suppl 1:78-82.

35. Guglielmone, A.A., Beati, L., Barros-Battesti, D.M., Labruna, M.B., Nava, S., Venzal, J.M., Mangold, A.J., Szabó, M. P. J., Martins, J.R., González-Acuña, D. and Estrada-Peña, A. (2006) Ticks (Ixodidae) on humans in South America. Exp. Appl. Acarol., 40(2): 83-100.

36. Labruna, M.B., Ogrzewalska, M., Martins, T.F., Pinter, A. and Horta, M.C. (2008) Comparative susceptibility of larval stages of Amblyomma aureolatum, Amblyomma cajennense, and Rhipicephalus sanguineus to infection by Rickettsia rickettsii. J. Med. Entomol., 45(6): 1156-1159.

37. Moreira, J.R. and Piovezan, U. (2005) Wildlife management concepts, management of problem population and the example of the capybara. Embrapa Genetic Resources and Biotechnology, Brasilia.

38. Almeida, A.M.R. (2012) A paisagem do parque Tingui Curitiba-PR - e a presença de capivara (Hydrochoerus hydrochaeris, Linnaeus, 1766). Master's Thesis in Engineering Forestry. Submitted to Federal University of Paraná, Curitiba, Brazil.

39. Szabó, M.P.J. (2010) Aspects of tick ecology in natural and anthropized environment of Brazil. In: International Congress of Acarology, 13, Abstract Book, Recife, Brazil. p271.

40. Ribeiro, K.T., Rocha, G.F.S., Saraiva, D.G., Silva, A.P., Vilela, D.A.R., Lima, P.C.S., Campos, I.B., Filippo, D.C., Nascimento, J.S. and Calic, S.B. (2010) From capybaras and ticks to a proposal of communication and management in the national park of Serra do Cipó to reduce health risks. Oecol. Aust., 14(3): 668-685.

41. Estes, J.A., Terborgh, J., Brashares, J.S., Power, M.E., Berger, J., Bond, W.J., Carpenter, S.R., Essington, T.E., Holt, R.D., Jackson, J.B.C., Marquis, R.J., Oksanen, L., Oksanen, T., Paine, R.T., Pikitch, E.K., Ripple, W.J., Sandin, S.A., Scheffer, M., Schoener, T.W., Shurin, J.B., Sinclair, A.R.E., Soulé, M.E., Virtanen, R. and Wardle, D.A. (2011) Trophic downgrading of planet earth. Science, 333: 301-306.

42. Soares, J.F., Soares, H.S., Barbieri, A.M. and Labruna, M.B. (2012) Experimental infection of the tick Amblyomma cajennense, cayenne tick, with Rickettsia rickettsii, the agent of Rocky Mountain spotted fever. Med. Vet. Entomol., 26: 139-151. 